\title{
Research Square \\ The formation of giant podiform chromitite by asthenospheric melts in supra-subduction zone environments
}

\section{Tao Ruan}

Institute of Geochemistry, Chinese Academy of Sciences

Hong Zhong ( $\sim$ Zhonghong@vip.gyig.ac.cn )

Institute of Geochemistry, Chinese Academy of Sciences

Jianming Zhu

China University of Geosciences (Beijing) https://orcid.org/0000-0003-4977-6072

\section{Zhong-Jie Bai}

State Key Laboratory of Ore Deposit Geochemistry, Institute of Geochemistry, Chinese Academy of Sciences, Guiyang 550081, China

\section{Article}

Keywords: podiform chromitite, SSZ

Posted Date: March 10th, 2021

DOl: https://doi.org/10.21203/rs.3.rs-225374/v1

License: (9) This work is licensed under a Creative Commons Attribution 4.0 International License. Read Full License 


\section{Abstract}

Podiform chromitite hosted in supra-subduction zone (SSZ) ophiolite accounts for a substantial proportion of the global chromium supply market. However, there is no consensus regarding the specific processes involved in the source and formation of this chromium. It seems unlikely that fractional crystallization of basaltic melt or the boninitic melt-mantle harzburgite reaction could provide such huge amounts of chromium given the constraints of $\mathrm{Cr}$ mass balance. Here we identify two specific melts responsible for the formation of the typical ophiolite-related Luobusa chromite deposit in the YarlungZangbo Suture Zone in Tibet, China. One is Cr-rich melt derived from the deep asthenosphere, and the other is boninitic melt generated by hydrous melting of previously depleted peridotites. We propose that the Luobusa podiform chromitite was produced through mixing of these two melts, of which the primitive asthenospheric $\mathrm{Cr}$-rich melt provided huge amounts of $\mathrm{Cr}$, and the introduction of boninitic magma triggered the crystallization of chromite. The findings of this study are important for understanding the genesis of global podiform chromite deposits hosted in SSZ ophiolite.

\section{Background}

Globally, chromite deposits are typically distributed in crustal sections of layered mafic-ultramafic intrusions (e.g., the Stillwater and Bushveld complexes) and mantle sequence of supra-subduction zone (SSZ) ophiolites (e.g., the Turkey and Oman ophiolites), and are defined as stratiform chromitite and podiform chromitite, respectively. These two types of chromitite serve as the two predominant sources of industrial chromium. Compared with the more well-established metallogenic mechanism for stratiform chromitite, the mechanism responsible for the generation of podiform chromitite has not yet reached consensus with respect to theoretical metallogeny ${ }^{1-3}$. The term "podiform chromitite" was defined by Thayer $^{4-5}$ in the 1960 s to describe lenticular chromite bodies hosted in Alpine ultramafic rocks and was subsequently applied to the case of chromite deposits in SSZ ophiolites. Although individual podiform chromite deposits may be inferior to stratiform chromite deposits in ore grade and deposit scale, they are more widely distributed and more numerous, making them of high economic interest. A database of current global chromium resources shows that $57.4 \%$ of chromite production is from podiform chromitite ${ }^{6}$. Importantly, podiform chromitite carries information about mantle processes, giving the potential to reveal details of magmatic evolution and crust-mantle interaction in SSZ environments. Podiform chromitite has therefore attracted considerable attention. However, although diverse models have been constructed to explain the formation of podiform chromitite, there is no clear consensus regarding a favored formation mechanism.

Prior to the 1990s, the prevailing view was that podiform chromitite formed through fractional crystallization of basaltic melts in magma chambers or magma conduits ${ }^{7-8}$, accompanied in some cases by magma segregation ${ }^{7}$. It has also been suggested that podiform chromitite represents the ultimate mantle residue ${ }^{9-10}$ after high-degree melting or formation by mingling of two end-member melts with different silica activities ${ }^{11}$. Since the 1990s, the melt-rock reaction model, which suggests that 
subduction-related melts (mostly with boninitic affinity) interact with mantle peridotites to form chromitite and associated dunite envelope ${ }^{1-2,12-13}$, has become widely accepted ${ }^{33,36-37}$. More recently, the identification of ultra-high pressure (UHP) minerals enclosed in chromitite has been an important step in the study of ophiolite and podiform chromitite ${ }^{14}$, from which two hypotheses for the genesis of podiform chromitite have been derived. The first is the mantle plume model, where chromitite might initially form within the mantle transition zone (MTZ, >300 km depth) then be transported to shallow mantle depths by a mantle plume ${ }^{15}$. The second is related to deep mantle recycling, in which case shallow-origin chromitite is subducted to the MTZ and then exhumed to the upper mantle by mantle convection ${ }^{16-18}$. To reconcile the contradictions between UHP minerals and the shallow origin of huge amounts of chromitite, Zhou et al. ${ }^{3}$ and Robinson et al. ${ }^{19}$ proposed alternative perspective where a magma conduit at depth whereby slab contamination of upwelling asthenospheric melt resulting from slab breakoff or tearing could precipitate chromite and thereafter bring UHP and crustal minerals to shallow levels.

These models for podiform chromitite formation, however, have not provided incontrovertible evidence as to where the huge amounts of chromium came from and how to accumulate. In the case of stratiform chromitite in the Bushveld Complex, mass balance calculations suggest that the volumes of magma that form chromitite layers by fractional crystallization are larger than the total volume of cumulate rocks ${ }^{20}$. Similarly, the "chromium paradox" ${ }^{20}$ can also be invoked in the case of podiform chromitite. The concentrations of chromium in primitive mantle-derived melts are known to be low; for example, 200-400 ppm $\mathrm{Cr}$ for MORB ${ }^{21}$ and 200-1800 ppm Cr for boninite ${ }^{22}$. In addition, $\mathrm{Cr}_{2} \mathrm{O}_{3}$ is a trace component (generally $<1 \mathrm{wt} \%$ ) in mantle pyroxenes. Thus, it seems unreasonable that the chromium required to feed giant podiform chromitite could have been derived from pyroxene by boninitic melt-mantle rock reaction or from primitive mantle-derived melts (MORB-like or arc magmas), given the chromium mass balance. This argument is supported by field observations, which show that larger massifs might not contain chromite bodies, and that giant chromite deposits can be hosted in small massifs. Furthermore, the scale of deposit is not related to the volume of associated volcanic rocks or mafic cumulate rocks. To reconcile the chromium paradox, we propose an evidence-based novel model in which a special Cr-rich melt that originates from the deep asthenosphere may play a dominant role as a chromium source, rather than normal mantle-derived melts. The reliability of this conjecture is confirmed by studying the Luobusa podiform chromitite located at the eastern Yarlung-Zangbo Suture Zone (YZSZ). The Luobusa massif covers a restricted area of $70 \mathrm{~km}^{2}$ and contains rare crustal components (basalts). The massif hosts the only economic podiform chromite deposit along the 2000-km YZSZ, and is the largest in China, with chromite reserves exceeding $6 \mathrm{Mt}^{23}$. Our study shows that the Luobusa chromitite gives direct insights into the sources of chromium in SSZ environments; i.e., the asthenosphere.

\section{Results}

Information about the tectonic background and location of the Luobusa massif is presented in Supplementary Fig. 1. Here we provide comprehensive geochemical data for mantle peridotites and podiform chromitites and associated dunite envelopes. Mantle peridotites were sampled away from 
gabbro layers or diabase sills and contain no obvious magmatic veins or plagioclases. Summary petrographic observations are presented in Supplementary Fig. 2. Chromitites show diversity in primary magmatic structures, including disseminated, nodular, anti-nodular, banded, and massive types (Supplementary Fig. 3). The complete geochemical results are given in Supplementary Data 1-3. Overall, the selected peridotite samples exhibit highly variable compositions. The average chromite $\mathrm{Cr}^{\#}(100 \times \mathrm{Cr} /$ [Cr+Al]) value ranges from 20 to 65 with good continuity, covering nearly the whole spectrum of abyssal peridotites ( $\mathrm{Fig} .2 \mathrm{~b}$ ). The $\mathrm{TiO}_{2}$ contents of accessory chromite are highly heterogeneous, ranging from 0 to $0.38 \mathrm{wt} \%$. Clinopyroxenes span a wide range of $\mathrm{Na}, \mathrm{Cr}$, and $\mathrm{Ti}$ contents over the whole sampling range, but show flat variations within individual samples. Clinopyroxene $\mathrm{Na}_{2} \mathrm{O}$ contents range from 0.1 to 1.3 $\mathrm{wt} \%, \mathrm{Cr}_{2} \mathrm{O}_{3}$ from 0.4 to $1.8 \mathrm{wt} \%$, and $\mathrm{TiO}_{2}$ from 0.01 to $0.40 \mathrm{wt} \%$. There are three distinctive $\mathrm{Cl}$-chondritenormalized REE patterns for clinopyroxenes (Figs. 1a-c). Amphiboles observed in four samples (Supplementary Figs. $2 \mathrm{~g}-\mathrm{h}$ ) show extreme enrichment in $\mathrm{Na}, \mathrm{Cr}$, and $\mathrm{Ti}$ contents, with $\mathrm{Na}_{2} \mathrm{O}$ contents of 3.0-4.0 wt $\%, \mathrm{Cr}_{2} \mathrm{O}_{3}$ of $2.0-3.5 \mathrm{wt} \%$, and $\mathrm{TiO}_{2}$ of $0.91-3.22 \mathrm{wt} \%$. The hydrous amphiboles have enigmatic REE characteristics, showing an arch-shaped REE pattern (Fig. 1d). Chromitite samples are high-Cr type with very homogeneous chromite $\mathrm{Cr}^{\#}$ values ( 80). The $\mathrm{TiO}_{2}$ contents of chromite vary from 0.10 to 0.26 wt\% and show a strong negative correlation with $\mathrm{Cr}^{\#}$ (Fig. 2b).

\section{Discussion}

Except for normal mantle residues that resemble abyssal peridotites ${ }^{24}$ and are consistent with previous studies ${ }^{25-26}$ with respect to clinopyroxene REE patterns (Fig. 1a), we distinguish another two groups of mantle peridotites on the basis of clinopyroxene and chromite compositions. We consider that these groups record two mantle processes involved with two specific melts in SSZ mantle. We further consider that these two specific melts could have been responsible for the formation of the typical Luobusa podiform chromite deposit in the Yarlung-Zangbo Suture Zone.

1) Hydrous melting to produce boninitic melt. Boninite is an essential petrological indicator for arc (subduction) environments ${ }^{27-30}$ and is characterized by high $\mathrm{MgO}\left(>8 \mathrm{wt} \%\right.$ ) and $\mathrm{SiO}_{2}(>52 \mathrm{wt} \%$ ) but extremely low $\mathrm{TiO}_{2}(<0.5 \mathrm{wt} \%)$ contents ${ }^{31}$. Early studies of rock geochemistry $22,27-28$ and recent experimental petrology ${ }^{29-30}$ have demonstrated that boninite is generated by a high degree of melting $(>20 \%)$ of refractory harzburgite fluxed by slab-derived fluids. In natural magma systems, podiform chromitite has similar trace-element and platinum group element patterns to those of boninites ${ }^{1,3,33-35}$. Therefore, the inferred parental melts of podiform chromitite exhibit a geochemical resemblance to boninitic melts, leading many researchers to support the boninitic affinity for the genesis of podiform chromitite ${ }^{33-37}$. Although boninite has not been reported previously for the Luobusa massif, we provide evidence of in-situ clinopyroxene trace-element compositions to support the existence of boninitic melt in the Luobusa mantle. 
First, the studied samples show an extremely depleted nature. Protogranular clinopyroxenes are very rare (total clinopyroxenes $<1 \%$ modal), and nearly invisible under the microscope (see Supplementary petrographic observations). They have very high chromite $\mathrm{Cr}^{\#}$ values (>55) and low clinopyroxene $\mathrm{Al}_{2} \mathrm{O}_{3}$ contents ( $<1.5 \mathrm{wt} \%$ ), clearly differing from typical abyssal peridotites (chromite $\mathrm{Cr}^{\#}<40$, clinopyroxene $\mathrm{Al}_{2} \mathrm{O}_{3}>3.0 \mathrm{wt} \%$ ). Second, these clinopyroxenes have flat REE patterns with pronounced LREE enrichment but HREE depletion compared with normal residual clinopyroxenes (Fig. 1b). Such less-fractionated REE trends are commonly seen in arc-related peridotites involved with hydrous melting ${ }^{38-43}$. Jean et al. ${ }^{40}$ and Le Roux et al. ${ }^{41}$ have noted that clinopyroxenes from SSZ peridotites have lower Dy and Yb contents than those of residual clinopyroxenes after anhydrous melting, which is consistent with our results (Fig. 3a). Third, a prominent feature of SSZ peridotites is the extreme depletion of $\mathrm{Ti}$ in clinopyroxenes, which is well documented by mantle wedge peridotites $(30-150 \mathrm{ppm})^{38}$, IBM forearc peridotites (86-156 ppm) ${ }^{39}$, recycled arc peridotites in oceanic mantle (60-120 ppm) ${ }^{43}$, and arc peridotite xenoliths (107-195 $\mathrm{ppm})^{44}$, as well as the Luobusa peridotites in this study $(170-250 \mathrm{ppm})$. Simulations have indicated that such clinopyroxenes simultaneously depleted in Ti and HREEs cannot be achieved by dry melting in a mid-ocean ridge (MOR) setting, but correspond perfectly to hydrous melting in a subduction setting ${ }^{38-43}$. According to modelling results, the melt in equilibrium with the clinopyroxenes characterized by such REEs and Ti compositions is most likely to be boninitic ${ }^{38,43}$. Importantly, these clinopyroxenes have similar REE patterns to those of clinopyroxenes from high-Ca boninite (Supplementary Fig. 4a), and the calculated melt in equilibrium with these clinopyroxenes exhibits similar REE patterns to that of boninite (Supplementary Fig. 4b). In addition, we observe that Sr, a fluid-mobile element, exhibits relatively higher contents than those of residual clinopyroxenes (0.50-1.29 vs $0.08-0.29 \mathrm{ppm})$. Variable-valence elements, such as $\mathrm{V}$ and $\mathrm{Mn}$, have lower concentrations compared with residual clinopyroxenes. This suggests that the ambient environment of these samples was more hydrous and oxidized, leading to higher Sr contents and the loss of high-valence ions of $\mathrm{V}$ and $\mathrm{Mn}$, as they could not be held in clinopyroxene crystals. Overall, our geochemical results are highly consistent with the hydrous melting of highly depleted peridotites, thus meeting the required conditions for the formation of boninitic magma. Hence, boninitic magma is expected to have been involved in the Luobusa mantle.

2) Cr-rich melt derived from the asthenosphere. Another group of mantle peridotites from the Luobusa massif has distinctive traits that are substantially different from those of abyssal and SSZ peridotites. These mantle peridotites display strong melt metasomatism recorded by mineral compositions. First, clinopyroxenes from these samples are strongly enriched in $\mathrm{Na}_{2} \mathrm{O}(>0.6 \mathrm{wt} \%), \mathrm{Cr}_{2} \mathrm{O}_{3}(\sim 1.0-1.9 \mathrm{wt} \%)$, and $\mathrm{Ti}$ (1000-2000 ppm). Na contents vary positively with $\mathrm{Cr}$ (Fig. 2a). Clinopyroxenes with such anomalous $\mathrm{Na}$ and $\mathrm{Cr}$ enrichments have been reported for some abyssal peridotites from slow-ultraslow spreading ridges, such as the Southwest Indian Ridge (SWIR) ${ }^{45-46}$, Lena Trough ${ }^{47}$, and Central Atlantic Ocean ${ }^{48}$, and have been interpreted as metasomatism involving alkaline (sodium) melt ${ }^{46-47}$ or asthenospheric melt ${ }^{45,48}$. Distinctive light to medium REE contents create unusual arched REE patterns (Fig. 1c), which is rare among global abyssal peridotites ${ }^{49}$, but is comparable with those of metasomatized peridotites from Lena Trough ${ }^{47}$. In addition, Sr and Zr contents of clinopyroxenes are too high to be explained by simple 
partial melting (e.g., mean values of 16 and 40 ppm, respectively, for sample 1829a). Second, the $\mathrm{Ti}$ contents of chromite are far beyond those of normal residual chromite. Dick et al. ${ }^{51}$ proposed that chromite $\mathrm{TiO}_{2}$ of residual peridotites is homogeneously less than $0.15 \mathrm{wt} \%$ and increases (to $>0.15 \mathrm{wt} \%$ ) when influenced by MORB-like liquids in MOR mantle. In addition, accessory chromites in harzburgite have lower $\mathrm{TiO}_{2}$ contents compared with metallurgical chromite from podiform chromitite ${ }^{3}$. However, our results show that these metasomatized chromites have higher $\mathrm{TiO}_{2}$ contents $(0.15-0.35 \mathrm{wt} \%)$ than those of chromites from residual peridotites, even higher than those of metallurgical chromites (Fig. 2b). Third, we observed many interstitial amphiboles in these samples (Supplementary Figs. $2 g-h$ ), a diagnostic mineral of melt metasomatism. The amphiboles show similar arched REE patterns (Fig. 1d), and also have high $\mathrm{Na}_{2} \mathrm{O}(3.0-4.0 \mathrm{wt} \%), \mathrm{Cr}_{2} \mathrm{O}_{3}(1.7-3.5 \mathrm{wt} \%)$, and $\mathrm{TiO}_{2}(1.0-3.0 \mathrm{wt} \%)$ contents. These observations strongly support a metasomatic origin for these samples.

Plagioclase-bearing ( $\mathrm{PI}-$ ) peridotites (maybe containing amphiboles) are common products of metasomatism of mantle-derived melts in SSZ and MOR mantle. Here, we confirm that the metasomatic agent is not normal mantle-derived magma, but rather Cr-rich melt originating from asthenospheric mantle. First, metasomatized chromites show a negative correlation between $\mathrm{Cr}^{\#}$ and $\mathrm{Ti}$, which is not seen in Pl-peridotite at the given $\mathrm{Cr}^{\#}$ of chromite (Fig. 2b). This trend is also opposite to that of melt-rock reaction, in which case $\mathrm{Cr}^{\#}$ covaries positively with $\mathrm{Ti}^{52}$. Second, the evidence for $\mathrm{Cr}$-rich agent metasomatism is supported by the extreme $\mathrm{Na}$ and $\mathrm{Cr}$ contents of clinopyroxenes. The positive trend for $\mathrm{Na}$-Cr differs from the geochemical feature for abyssal residual and PI-peridotites but overlaps the field of asthenospheric melt metasomatic clinopyroxenes from the SWIR ${ }^{45}$ (Fig. 2a). We observe that $\mathrm{Na}$ content increases with decreasing $\mathrm{Ti}$ in clinopyroxenes. Although the precision and accuracy of $\mathrm{Na}$ contents analyzed by LA-ICP-MS are poor, Hellebrand and Snow ${ }^{47}$ pointed out that $\mathrm{Na}$ and $\mathrm{Nd}$ should exhibit similar behaviors during magmatic processes, given their close partition coefficients between silicate melts and clinopyroxenes. Therefore, we utilized $\mathrm{Nd}$ to substitute for $\mathrm{Na}$ to plot a $\mathrm{Ti}-\mathrm{Nd}$ diagram (Fig. 3b). The metasomatized samples define a unique negative trend that differs from both residual and veined peridotites from the compilation by Warren ${ }^{49}$. Additionally, clinopyroxenes have distinctive arched REE patterns with no Eu anomaly, which is different from typical Pl-peridotites from SSZ ${ }^{53}$ or MOR ${ }^{54}$ mantle. Third, the REE patterns of interstitial amphiboles differ substantially from those of their counterparts from sub-arc ${ }^{55}$ and sub-ridge mantle ${ }^{56}$ (Fig. 1d). These results thus strongly suggest that 1 ) the metasomatic agent is rather rich in $\mathrm{Cr}$, and 2) the metasomatic agent is not normal mantle-derived magma such as MORB-like or subduction-related (arc) melts, but is instead inferred to be derived from the deep asthenosphere.

\section{Cr isotope constraints}

Stable $\mathrm{Cr}$ isotopes have been widely applied to the study of high-temperature geological processes and have also allowed significant progress to be made in exploring planetary evolution. We therefore attempted to utilize $\mathrm{Cr}$ isotope compositions to constrain the mantle evolutions involved with two specific magmas identified in the Luobusa mantle. Before conducting a detailed investigation, the possibility that 
kinetic diffusion and weathering (or water) alteration could obliterate the original $\mathrm{Cr}$ signatures should be excluded. Given the high $\mathrm{Cr}$ contents in chromite compared with those of co-existing silicate minerals, it is considered that the $\mathrm{Cr}$ isotope signatures of chromite are negligibly affected by late chemical diffusion. Therefore, fresh bulk rocks with loss-on-ignition values of $<4 \mathrm{wt} \%$ and chromite separates were chosen for measurement. The results of $\mathrm{Cr}$ isotope compositions is given in Supplementary Data 3.

\section{Whole-rock $\mathrm{Cr}$ isotope compositions}

Overall, the whole-rock $\mathrm{Cr}$ isotope values vary positively with chromite $\mathrm{Cr}^{\#}$ (Fig. 4a). Residual peridotites have the lowest $\delta^{53} \mathrm{Cr}$ values of $-0.21 \%$ o to $-0.14 \%$, whereas metasomatized peridotites modified by $\mathrm{Cr}$ rich asthenospheric melt have higher values of $-0.11 \%$ o to $-0.08 \%$ o. Two SSZ peridotite samples in equilibrium with boninitic melt exhibit the highest $\mathrm{Cr}$ isotope compositions of $0.03 \%$ ond $0.04 \%$ o. In addition, we analyzed two dunite envelopes with sharp boundaries contacting chromitite, which show similar values $(0.02 \%$ ond $0.04 \%$ o) to those of SSZ peridotites, indicating that the envelopes are also equilibrated with boninitic melt and might have been formed by melt-rock reaction following the model of Zhou et al. ${ }^{13}$. These results show that whole-rock $\mathrm{Cr}$ isotope compositions can distinguish our SSZ and metasomatized peridotites, perhaps reflecting the different nature of the two melts involved.

\section{Chromite Cr isotope variations}

The $\mathrm{Cr}$ isotope variations of chromite from peridotites and chromitites show a wide range of $-0.38 \%$ o to $0.03 \%$ o (Fig. 4b). Residual chromites are characterized by negative $\delta^{53} \mathrm{Cr}$ values, ranging from $-0.21 \%$ o to $-0.38 \%$, which are much lower than the global mantle-derived chromites $(-0.079 \%$ o $\pm 0.129 \%, n=42)$ compiled by Farkaš et al. ${ }^{57}$ In that compilation, most chromites were from arc environments. Our lower values indicate that depleted MORB mantle (DMM) has relatively light chromite $\mathrm{Cr}$ isotope compositions, whereas SSZ mantle contaminated by subduction slabs should exhibit heavy $\mathrm{Cr}$ isotope signatures. Metasomatized chromites have slightly heavy $\delta^{53} \mathrm{Cr}$ values of $-0.14 \%$ ond $-0.15 \%$. Chromites from the podiform chromitite exhibit uniform $\mathrm{Cr}$ isotope signatures of $-0.10 \%$ o to $-0.13 \%$, meaning that the oreforming chromites have the closest $\mathrm{Cr}$ isotope composition to those of metasomatized chromites. Therefore, we consider that these chromitites are also equilibrated with $\mathrm{Cr}$-rich asthenospheric melt. Chromites from the dunite envelopes have higher $\delta^{53} \mathrm{Cr}$ values $(0.00 \%$ o to $0.03 \%$ o) compared with the ore-forming chromites, although they have identical $\mathrm{Cr}^{\#}$ values.

Overall, from the view of $\mathrm{Cr}$ isotope compositions of whole-rock and chromite separates, we consider that 1) two types of peridotite that equilibrated with Cr-rich asthenospheric melt and boninitic melt are reflected in their different $\mathrm{Cr}$ isotope characteristics; and 2) the ore-forming chromites are equilibrated with Cr-rich asthenospheric melt, whereas the dunite envelopes are equilibrated with boninitic melt.

\section{The origin of podiform chromitite}

Our preferred interpretation for the origin of podiform chromitite is that primitive Cr-rich asthenospheric melt mixes with boninitic magma to form chromitite, in which case, the Cr-rich melt provides the majority 
of $\mathrm{Cr}$, and the mixing process triggers chromite saturation and crystallization (Fig. 5). When oceanic lithosphere is subducted, fluids derived from the subducted slab cause hydrous melting of refractory harzburgite to produce boninitic melt. This magma would interact extensively with mantle peridotites to form dunite. Large chromitite bodies would not form if there were insufficient amounts of $\mathrm{Cr}$. As the slab continues to sink deeper, owing to the density contrast resulting from different degrees of metamorphism, the oceanic lithosphere breaks off to form a slab window. The window facilitates upwelling of asthenospheric material. As asthenospheric melts ascend along magma conduits to the shallow mantle, Ti-depleted boninitic melts that widely infiltrate within peridotites are added to upwelling Cr-rich asthenospheric melts. This addition causes the new magma system to become more enriched in Si and $\mathrm{Mg}$ but depleted in Ti, more hydrous and oxidized, thus trigging the crystallization of chromite. We figuratively refer to this system as a "chromite-producing factory" (Fig. 5). Chromite crystals do not accumulate significantly at depth. Field observations show that the major chromitite bodies are restricted to the shallow mantle-crust transition zone or uppermost mantle ${ }^{1-3}$, indicating that they were deposited directly at the transition zone. It has been demonstrated experimentally that water bubbles can enclose chromite crystals to migrate upward more efficiently under the enhanced buoyancy ${ }^{58}$. Therefore, we suggest that chromites were suspended in Cr-saturated magma and carried upward more effectively by a fluid phase. When arriving at the crust-mantle transition zone, chromites would be accumulated to form podiform chromitite owing to the marked drop in temperature and pressure. Fluid would then be separated from the magma system, causing mobile elements (e.g., $\mathrm{Na}, \mathrm{Sr}, \mathrm{Zr}$, and LREEs) to be extracted from melt and enter the fluid, as they are more soluble in water than in melt. The high-temperature fluid thereafter infiltrated the wall rock to form clinopyroxene enriched in $\mathrm{Cr}, \mathrm{Ti}, \mathrm{Na}, \mathrm{Sr}, \mathrm{Zr}$, and hydrous amphibole (which was also enriched in $\mathrm{Cr}, \mathrm{Ti}, \mathrm{Na}, \mathrm{Sr}$, and $\mathrm{Zr}$ ). Assuming that the supply rate of $\mathrm{Cr}$-rich asthenospheric melt is stable, the continuous input of Ti-depleted boninitic melt would cause the magma system to contain less $\mathrm{Ti}$ and more hydrous phases. Magmas with higher water contents have a higher ability to carry REEs. This explains the increase in REE contents with increasing $\mathrm{Na}$ and $\mathrm{Cr}$ but decreasing $\mathrm{Ti}$ in clinopyroxene (as well as amphibole), as well as the negative correlations between $\mathrm{Cr}^{\#}$ and $\mathrm{TiO}_{2}$ in metasomatic chromites and ore-forming chromites.

\section{Implications}

Podiform chromitite hosted in ophiolite plays an important role in the global production of metallurgical chromite. Several pioneering models have been established to decipher their formation, but as yet no agreement has been reached on the mechanism of formation. Our assessment of the main concepts of these models suggests that the inferred source of $\mathrm{Cr}$ is inevitably basaltic or boninitic melt. It is proposed here, however, that neither of these melts can directly be the parental magma of podiform chromitite owing to low $\mathrm{Cr}$ solubility. Our study has postulated another source of $\mathrm{Cr}$ to feed the huge accumulation of chromite involved in podiform chromitites, which should prove important for understanding and assessing the metallogenic potential of ophiolitic chromitite. The abnormal enrichment of elements such as $\mathrm{Na}, \mathrm{Ti}, \mathrm{Cr}, \mathrm{Zr}$, Hf, LREE in clinopyroxene and amphibole and $\mathrm{Ti}$ in chromite could be an indicator of ore prospectivity in the future. 
From a global perspective, our proposed model provides another possibility for the genesis of podiform chromitite except the widely accepted melt-rock reaction model. Many ophiolite massifs host sparse, small-scale chromitite occurrences (chromite mineralization) that lack economic value. This can be explained by a lack of a sufficient $\mathrm{Cr}$ source, such as deep and Cr-rich asthenospheric melt. Melt-rock reaction alone might not yield the amount of $\mathrm{Cr}$ required to supply a giant chromite deposit. We consider that many economic podiform chromitites were formed by a similar process during which asthenospheric Cr-rich melt made a crucial contribution. However, both SSZ mantle and modern MOR mantle can be modified by asthenospheric melt, and ophiolite represents ancient oceanic lithosphere, or in other words, modern oceanic lithosphere will become SSZ ophiolite in the future. With respect to this study, a question arises as to why economic podiform chromitite deposits are hardly observed in modern oceanic mantle? Reasonable explanations for this observation might include the following:

1) Cr-rich melt. Despite the evidence supporting the metasomatism of asthenospheric melt in modern oceanic mantle, the occurrence of such metasomatism is rare. The most common metasomatic agents are MORB-like melts, rather than asthenospheric Cr-rich melts or boninitic melts. With respect to the dynamics of subduction, the interference of the subducting slab within the mantle can disturb the previous internal material balance by dynamics processes such as slab retreat, breakoff, or tearing. These processes can effectively trigger the upwelling of deep asthenospheric melt. It should be emphasized that such asthenospheric melt must be Cr-rich so that it can provide sufficient $\mathrm{Cr}$ to form economic chromite deposits.

2) Water. Edwards et a $\left.\right|^{59}$ proposed that almost all parental melts of podiform chromitite demand the introduction of water, as water can substantially increase the $\mathrm{Cr}$ solubility of melts. We suggest that this component plays a crucial role both in forming chromite-saturated magmas and in transporting chromite to the crust-mantle transition zone to form deposits. In SSZ environments, mantle wedge fluxed with fluid from slab dehydration is a common process. Conversely, the lack of water in MOR mantle makes it difficult to meet the conditions for producing boninitic melt and podiform chromitite.

\section{Methods}

Electron probe microanalysis (EPMA). Major-element compositions of chromite and clinopyroxene were obtained using a JEOL JXA8530F-plus field emission electron probe equipped with an energy dispersive spectroscopy system at the State Key Laboratory of Deposit Geochemistry, Institute of Geochemistry, Chinese Academy of Sciences, Guiyang, China. The analyses were conducted under conditions of $20 \mathrm{nA}$ beam current and $20 \mathrm{kV}$ accelerating voltage. The beam size was selected on the basis of the size of target grains, with a $10 \mu \mathrm{m}$ diameter circular beam for larger grains and 2-5 $\mu \mathrm{m}$ for smaller grains. Typically, $20 \mathrm{~s}$ and $10 \mathrm{~s}$ were assigned to peak and background counting times, respectively. Analyses of particular elements used $\sim 40 \mathrm{~s}$ for peak counting time, such as $\mathrm{Ti}(40 \mathrm{~s})$ and $\mathrm{Ni}(37 \mathrm{~s}$ ) of chromite, $\mathrm{Ti}$ (40 s) and $\mathrm{Cr}$ (40 s) of clinopyroxene and amphibole, and $\mathrm{Ni} \mathrm{(33s)} \mathrm{of} \mathrm{olivine.} \mathrm{Natural} \mathrm{and} \mathrm{synthetic} \mathrm{standards}$ were used for calibration. A ZAF correction was used to process the raw data. An individual analysis was discarded if the total weight deviated by $>2 \mathrm{wt} \%$ from $100 \mathrm{wt} \%$. 
Laser ablation-inductively coupled plasma-mass spectrometry (LA-ICP-MS). In situ trace-element compositions of clinopyroxene and amphibole were determined using a $193 \mathrm{~nm}$ Coherent Geolas Pro ArF Excimer laser coupled to a Thermo Scientific Element XR high-resolution ICP-MS instrument at the State Key Laboratory of Deposit Geochemistry, Institute of Geochemistry, Chinese Academy of Sciences. To ensure sufficient sample injection, we used a large beam diameter of $60 \mu \mathrm{m}$ at an ablation rate of $10 \mathrm{~Hz}$, with an energy density of $6 \mathrm{~mJ} / \mathrm{cm}^{2}$, and $18 \mathrm{~s}$ analysis time for the gas blank and $\sim 40 \mathrm{~s}$ for sample collection. NIST 610, NIST 612, BHVO-2G, BCR-2G, and BIR-1G were used as external standards for calibration. The ${ }^{43} \mathrm{Ca}$ content determined by EPMA were used as an internal standard. The glass BCR-2G was treated as an unknown sample to assess data quality. Offline data were processed using ICPMSDataCal.11 software applying a multiple-reference material calibration combined with internal standard normalization ${ }^{60}$. The corrected results for BCR-2G fit closely to standard values. The Ti contents of clinopyroxene measured by EPMA are reliable when the individual analyzed result is $>3$ times the detection limit $(1 \sigma)$. These EPMA results $(>3 \sigma)$ are consistent with laser data, further confirming the validity of the laser data.

Double-spike MC-ICP-MS method for stable $\mathrm{Cr}$ isotope compositions. Determinations of $\mathrm{Cr}$ isotope compositions were performed by applying the double-spike MC-ICP-MS method at the State Key Laboratory of Geological Processes and Mineral Resources, China University of Geosciences, Beijing, China. The column chemistry followed Zhu et al ${ }^{61}$. Briefly, three columning processes were needed to purify $\mathrm{Cr}$ from solutions. First, a continuous two-stage column containing $2 \mathrm{~mL}$ cation resin AG50W-X8 (200-400 m) and $2 \mathrm{~mL}$ anion resin AG1-X8 resin (100-200 m) was used to remove $\mathrm{Ca}, \mathrm{Fe}, \mathrm{Cu}$, and $\mathrm{Zn}$. Second, a $1 \mathrm{~mL}$ AG1-X8 resin (200-400 m) column was used to remove most cations ( $>99 \% \mathrm{Ca}$, Fe, and $\mathrm{Ti}$, and $>90 \% \mathrm{~V}$ ). Third, the sample solutions needed to be artificially adjusted to neutral to slightly alkaline by mixing with $10 \mu \mathrm{L} 6.7 \mathrm{~N} \mathrm{NH}_{3} \cdot \mathrm{H}_{2} \mathrm{O}, 0.5 \mathrm{~mL} 0.2 \mathrm{M}(\mathrm{NH} 4)_{2} \mathrm{~S}_{2} \mathrm{O}_{8}$, and $4.44 \mathrm{~mL} \mathrm{MQ}$ water. The mixing solutions were heated at $140{ }^{\circ} \mathrm{C}$ for 3 hours to be oxidized. After full oxidation, the solutions were centrifuged to remove Mn, Al, Mg, and trace Ti and V. Finally, $2 \mathrm{~mL}$ of AG1-X8 anion resin was used to purify $\mathrm{Cr}$ from the supernatants.

\section{Declarations}

\section{Acknowledgements}

This study is supported by the Second Tibetan Plateau Scientific Expedition and Research (SETP) (2019QZKK0807) and the National Natural Science Foundation of China (41425011). We thank lab technician Wen-Qin Zheng, Xiang Li and Yun Li for their dutiful guidance in electron probe microanalyses, and Yan-Wen Tang in LA-ICP-MS analyses and data calibration. We thank Mr. Ouyang, the production supervisor of the Luobusa mining area, for sharing precious samples and assistance in field investigation and sampling. Guang-Liang Wu is thanked for his assistance in the digestion of samples for $\mathrm{Cr}$ isotope composition analyses.

\section{Author contributions}


Hong Zhong and Tao Ruan initiated the project as part of T. R.'s PhD. T.R. gathered electron probe and LA-ICP-MS data, drew the figures and completed the initial draft of the paper. Hong Zhong secured funding and revised the paper. Zhong-Jie Bai checked all figures and put forward correcting suggestions. Jian-Ming Zhu conducted Cr isotope analyses and contributed to the paper.

\section{Competing interests}

The authors declare no competing interests.

\section{References}

1. González-Jiménez, J. M., Griffin, W. L., Proenza, J. A., Gervilla, F., O’Reilly, S. Y., Akbulut, M., Pearson, N. J. \& Arai, S. Chromitites in ophiolites: how, where, when, why?, Part II. A review and new ideas on the crystallization of chromitites. Lithos189, 140-158 (2013).

2. S. \& Miura. M. Formation and modification of chromitites in the mantle. Lithos264, 277-295 (2016).

3. Zhou, M. F., Robinson, P. T., Su, B. X., Gao, J. F., Li, W., Yang, J. S. \& Malpas, J. Compositions of chromite, associated minerals, and parental magmas of podiform chromite deposits: the role of slab contamination of asthenospheric melts in suprasubduction zone environments. Gondwana Res.26, 262-283 (2014).

4. Thayer, T. P. Some critical differences between alpinetype and stratiform peridotite-gabbro complexes. International Geologic Congress Report, 21st Session, Norden, 13, 247-259 (1960).

5. Thayer, T. P. Principal features and origin of podiform chromite deposits, and some observations on the Guleman-Soridag district, Turkey. Geol.59, 1497-1524 (1964).

6. Mosier, D. L., Singer, D. A., Moring, B. C. \& Galloway, J. P. Podiform chromite deposits-database and grade and tonnage models. US Geological Survey Scientific Investigations Report, 5157 (2012).

7. Dickey, J. S. A hypothesis of origin for podiform chromite deposits. Cosmochim. Acta 39, 1061-1074 (1975).

8. Lago, B., Rabinowicz, M. \& Nicolas, A. Podiform chromite ore bodies: a genetic model. Petrol. 23, 103-125 (1982).

9. Wang, X. B. \& Bao, P. S. The genesis of podiform chromite deposits-A case study of the Luobusa chromite deposit, Tibet. Geol. Sinica. 2, 166-181 (1987).

10. S. Dunite-Harzburgite-Chromitite complexes as refractory residue in the Sangun-Yamaguchi Zone, Western Japan. J. Petrol. 21, 141-165 (1978).

11. Ballhaus, C. Origin of podiform chromite deposits by magma mingling. Earth Planet. Sci. Lett. 156, 185-193 (1998).

12. Arai, S. \& Yurimoto, H. Podiform chromitites of the Tari-Misaka ultramafic complex, Southwest Japan, as mantle-melt interaction products. Geol. 89, 1279-1288 (1994).

13. Zhou, M. F., Robinson, P. T. \& Bai, W. J. Formation of podiform chromites by melt-rock interaction in the upper mantle. Depos.29, 98-101 (1994). 
14. Yang, J. S. et al. Diamond- and coesite-bearing chromitites from the Luobusa ophiolite, Tibet. Geology35, 875-878 (2007).

15. Yang, J. S., Robinson, P. T. \& Dilek. Y. Diamonds in Ophiolites. Elements10, 127-130 (2014).

16. Arai, S. Conversion flow-pressure chromitites to ultrahigh-pressure chromitites by deep recycling: a good inference. Earth Planet. Sci. Lett. 379, 81-87 (2013).

17. McGowan, N. M. et al. Tibetan chromitites: Excavating the slab graveyard. Geology43, 179-182 (2015).

18. Griffin, W. L. et al. Mantle recycling: transition zone metamorphism of Tibetan ophiolitic peridotites and its tectonic implications. Petrol. 57, 655-684 (2016).

19. Robinson, P. T. et al. The origin and significance of crustal minerals in ophiolitic chromitites and peridotites. Gondwana Res.27, 486-506 (2015).

20. Eales, H. V. \& Costin, G. Crustally Contaminated Komatiite: Primary Source of the Chromitites and Marginal, Lower, and Critical Zone Magmas in a Staging Chamber Beneath the Bushveld Complex. Geol.107, 645-665 (2012).

21. Gale, A., Dalton, C. A., Langmuir, C. H., Su, Y. J. \& Schilling, J. G. The mean composition of ocean ridge basalts. Geophys. Geosyst. 14, 489-518 (2013).

22. Hickey, R. L \& Frey, F. A. Geochemical characteristics of boninite series volcanics: implications for their source. Cosmochim. Acta 46, 2099-2115 (1982).

23. Wang, Y., Zhong, H., Cao, H. Y., Wei, B. \& Chen. C. Genetic classification, distribution and ore genesis of major PGE, Co and Cr deposits in China: a critical review. Sci. Bull, 65, 3825-3838 (2020).

24. Johnson, K. T. M., Dick, H. J. B. \& Shimizu, N. Melting in the oceanic upper mantle: an ionmicroprobe study of diopsides in abyssal peridotites. Geophys. Res. 95, 2661-2678 (1990).

25. Zhang, P. F. et al. Evolution of nascent mantle wedges during subduction initiation: Li-O isotopic evidence from the Luobusa ophiolite, Tibet. Cosmochim. Acta, 245, 35-58 (2018).

26. Zhang, C., Liu, C. Z., Liu, T. \& Wu, F. Y. Evolution of mantle peridotites from the Luobusa ophiolite in the tibetan plateau: Sr-Nd-Hf-Os isotope constraints. Lithos, 362-363, 1-12 (2020).

27. Crawford, A. J., Falloon, T. J. \& Green, D. H. Classification, petrogenesis and tectonic setting of boninites, in Crawford, A. J., Ed., Boninites and Related Rocks: London, Unwin Hyman, 1-49 (1989).

28. Taylor, R. N., Nesbitt, R. W., Vidal, P., Harmon, R. S., Auvray, B. \& Croudace, I. W. Mineralogy, chemistry, and genesis of the boninite series volcanics, Chichijima, Bonin Islands, Japan. Petrol. 35(3), 577617.

29. Umino, S., Kitamura, K., Kanayama, K., Tamura, A., Sakamoto, N., Ishizuka, O. \& Arai, S. Thermal and chemical evolution of the subarc mantle revealed by spinel-hosted melt inclusions in boninite from the Ogasawara (Bonin) Archipelago. Geology43, 151-154 (2015).

30. Bénard, A., Nebel, O., Ionov, D. A., Arculus, R. J., Shimizu, N. \& Métrich, N. Primary silica-rich picrite and high-Ca boninite melt inclusions in pyroxenite veins from the Kamchatka sub-arc mantle. Petrol. 57(10), 1955-1982 (2016). 
31. LeBas, M. J. IUGS reclassification of the high-Mg and picritic volcanic rocks. Petrol. 41(10), 1467$1470(2000)$.

32. Sun, S. S. \& McDonough, W. F. Chemical and isotopic systematics of oceanic basalts: implications for mantle composition and processes. Soc. Lond.42, 313-345 (1989).

33. Pagé, P. \& Barnes, S. -J. Using trace elements in chromites to constrain the origin of podiform chromitites in the Thetford Mines Ophiolite, Québec, Canada. Econ Geol, 104, 997-1018 (2009).

34. Barnes, S. J. \& Roeder, P. L. The range of spinel compositions in terrestrial mafic and ultramafic rocks. Petrol, 42, 2279-2302 (2001).

35. M, F. Sun, M., Keays, R, R. \& Kerrich, R, W. Controls on platinum-group elemental distributions of podiform chromitites: A case study of high-Cr and high-Al chromitites from Chinese orogenic belts. Geochim. Cosmochim. Acta62, 677-688 (1998).

36. Uysal, I. et al. Petrology of Al- and Cr-rich ophiolitic chromitites from the Muğla, SW Turkey: implications from composition of chromite, solid inclusions of platinum-group mineral, silicate, and base-metal mineral, and Os-isotope geochemistry. Miner. Petrol. 158, 659-674 (2009).

37. Gervilla, F. et al. Distribution of platinum-group elements and Os isotopes in chromite ores from Mayarí-Baracoa Ophiolitic Belt (eastern Cuba). Miner. Petrol. 150, 589-607 (2005).

38. Bizimis, M., Salters, V. J. M. \& Bonatti, E. Trace and REE content of clinopyroxenes from suprasubduction zone peridotites. Implications for melting and enrichment processes in island arcs. Geol. $165,67-85$ (2000).

39. Parkinson, I. J., Pearce, J. A., Thirwall, M. F., Johnson, K. T. M. \& Ingram, G. Trace element geochemistry of peridotites from the Izu-Bonin-Mariana forearc, Leg 125. Ocean Drill. Program Sci. Results 125, 487-506 (1992).

40. Jean, M. M., Shervais, J. W., Choi, S. H. \& Mukasa, S. B. Melt extraction and melt refertilization in mantle peridotite of the Coast Range ophiolite: an LAICP-MS study. Miner. Petrol.159, 113-136 (2010).

41. Le Roux, V., Dick, H. J. B. \& Shimizu, N. Tracking flux melting and melt percolation in suprasubduction peridotites (Josephine ophiolite, USA). Miner. Petrol.168, 1064 (2014).

42. Shervais, J. W. \& Jean, M. M. Inside the subduction factory: Modeling fluid mobile element enrichment in the mantle wedge above a subduction zone. Cosmochim. Acta, 95, 270-285 (2012).

43. Urann, B. M., Dick, H. J. B., Parnell-Turner, R. \& Casey, J. F. Recycled arc mantle recovered from the Mid-Atlantic Ridge. Comm. 11, 3887 (2020).

44. Gregoire, M., Mclnnes, B. I . A. \& O'Reilly, S. Y. Hydrous metasomatism of oceanic sub-arc mantle, Lihir, Papua New Guinea - part 2. Trace element characteristics of slab-derived fluids. Lithos59, 91108 (2001).

45. Seyler, M., Lorand, J.-P., Toplis, M.J. \& Godard, G. Asthenospheric metasomatism beneath the midocean ridge: evidence from depleted abyssal peridotites. Geology 32 (4), 301-304 (2004). 
46. Sodium chromium covariation in residual clinopyroxenes from abyssal peridotites sampled in the $43^{\circ}-46^{\circ} \mathrm{E}$ region of the Southwest Indian Ridge.

47. Hellebrand, E. \& Snow, J. E. Deep melting and sodic metasomatism under-neath the highly obliquespreading Lena Trough (Arctic Ocean). Earth Planet. Sci. Lett. 216, 283-299 (2003).

48. D \& Seyler. M. Asthenospheric percolation of alkaline melts beneath the St. Paul region (Central Atlantic Ocean). Earth Planet. Sci. Lett. 289, 393-405 (2010).

49. Warren, J. M. Global variations in abyssal peridotite compositions. Lithos248-251, 193-219 (2016).

50. Warren, J. M. \& Shimizu. N. Cryptic variations in abyssal peridotite compositions: evidence for shallow-level melt infiltration in the oceanic lithosphere. Petrol. 51, 395-423 (2010).

51. Dick, H. J. B., Lissenberg, C. J. \& Warren, J. M. Mantle melting, melt transport and delivery beneath a slow-spreading ridge: the paleo-MAR from $23^{\circ} 15 \rrbracket \mathrm{N}$ to $23^{\circ} 45 \rrbracket \mathrm{N}$. Petrol. 51, 425-467 (2010).

52. Pearce, J. A., Barker, P. F., Edwards, S. J., Parkinson, I. J. \& Leat, P. T. Geochemistry and tectonic significance of peridotites from the South Sandwich arc-basin system, South Atlantic. Miner. Petrol.139, 36-53 (2000).

53. Müntener. O. et al. Refertilization of mantle peridotite in embryonic ocean basins: trace element and $\mathrm{Nd}$ isotopic evidence and implications for crust-mantle relationships. Earth Planet. Sci. Lett. 221, 293-308 (2004).

54. Mallick, S. et al. Isotope and trace element insights into heterogeneity of subridge mantle. Geophys. Geosyst. 15, 2438-2453 (2014).

55. M. et al. Amphiboles from suprasubduction and intraplate lithospheric mantle. Lithos 99, 68-84 (2007).

56. Cipriani, A. et al. A 19 to $17 \mathrm{Ma}$ amagmatic extension event at the Mid-Atlantic Ridge: ultramafic mylonites from the Vema Lithospheric Section. Geophys. Geosyst. 10, Q10011 (2009).

57. Farkaš, J. et al. Chromium isotope variations $\left(\delta^{53 / 52} \mathrm{Cr}\right)$ in mantle-derived sources and their weathering products: Implications for environmental studies and the evolution of $\delta^{53 / 52} \mathrm{Cr}$ in the Earth's mantle over geologic time. Cosmochim. Acta, 123, 74-92 (2013).

58. Matveev, S. \& Ballhaus, C. Role of water in the origin of podiform chromitite deposits. Earth Planet. Sci. Lett. 203, 235-243 (2002).

59. Edwards, S. J., Pearce, J. A. \& Freeman, J. New insights concerning the influence of water during the formation of podiform chromitite. in Dilek, Y., Moores, E. M., Elthon, D. \& Nicolas, A., eds., Ophiolites and Oceanic Crust: New Insights from Field Studies and the Ocean Drilling Program: Boulder, Colorado, Soci. Amer. Spec. Pap, 349, 139-147 (2000).

60. Liu, Y. S. et al. In situ analysis of major and trace elements of anhydrous minerals by LA-ICP-MS without applying an internal standard. Geol, 257(1-2): 34-43 (2008).

61. Zhu, J. M., Wu, G. L., Wang, X. L., Han, G. L. \& Zhang, L. X. An improved method of Cr purification for high precision measurement of $\mathrm{Cr}$ isotopes by double spike MC-ICP-MS. Anal. At. Spectrom. 33, 809-821 (2018). 
62. Mathez, E. A. \& Mey, J. L. Character of the UG2 chromitite and host rocks and petrogenesis of its pegmatoidal footwall, northeastern Bushveld Complex. Geol.100, 1617-1630 (2005).

Figures

Fig. 1
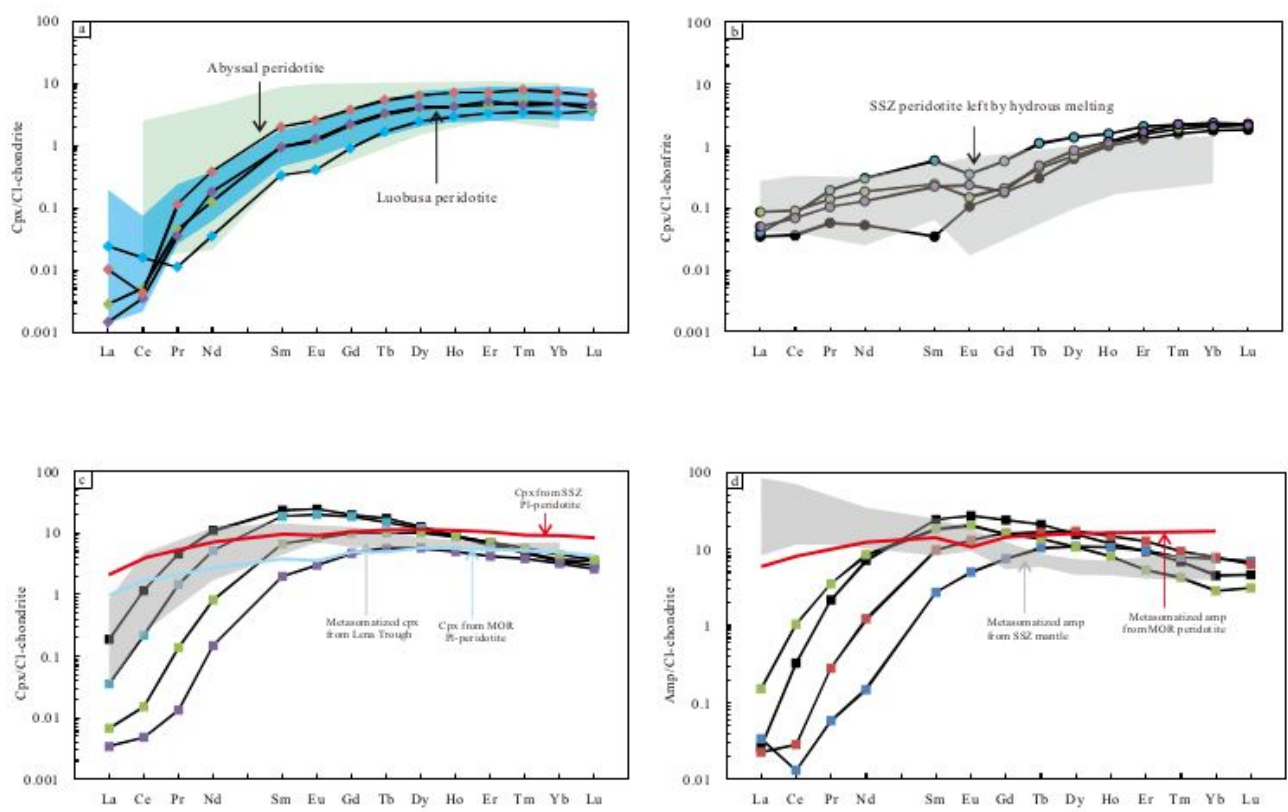

Figure 1 
Chondrite-normalized REE patterns of clinopyroxene and amphibole. a) Normal residual clinopyroxene after anhydrous melting. The green field represents global abyssal peridotites 24 and the blue field is from the previous studies of the Luobusa massif25-26. b) SSZ clinopyroxene left by hydrous melting. The gray background area represents clinopyroxene that underwent hydrous melting, which would produce boninitic melt38. c) Metasomatized clinopyroxene by Cr-rich asthenospheric melt. The arched patterns are comparable with those from the Lena Trough47. Red and light-blue lines represent clinopyroxenes from PI-peridotites from MOR53 and SSZ54 mantle, respectively. d) Amphiboles from metasomatized peridotites. Amphiboles show a similar arched trend to the paragenesis of clinopyroxene but differ from Pl-peridotites from sub-arc (gray area) 55 sub-ridge (red line) 56 and mantle. Chondrite-normalized values follow Sun and McDonough32. 

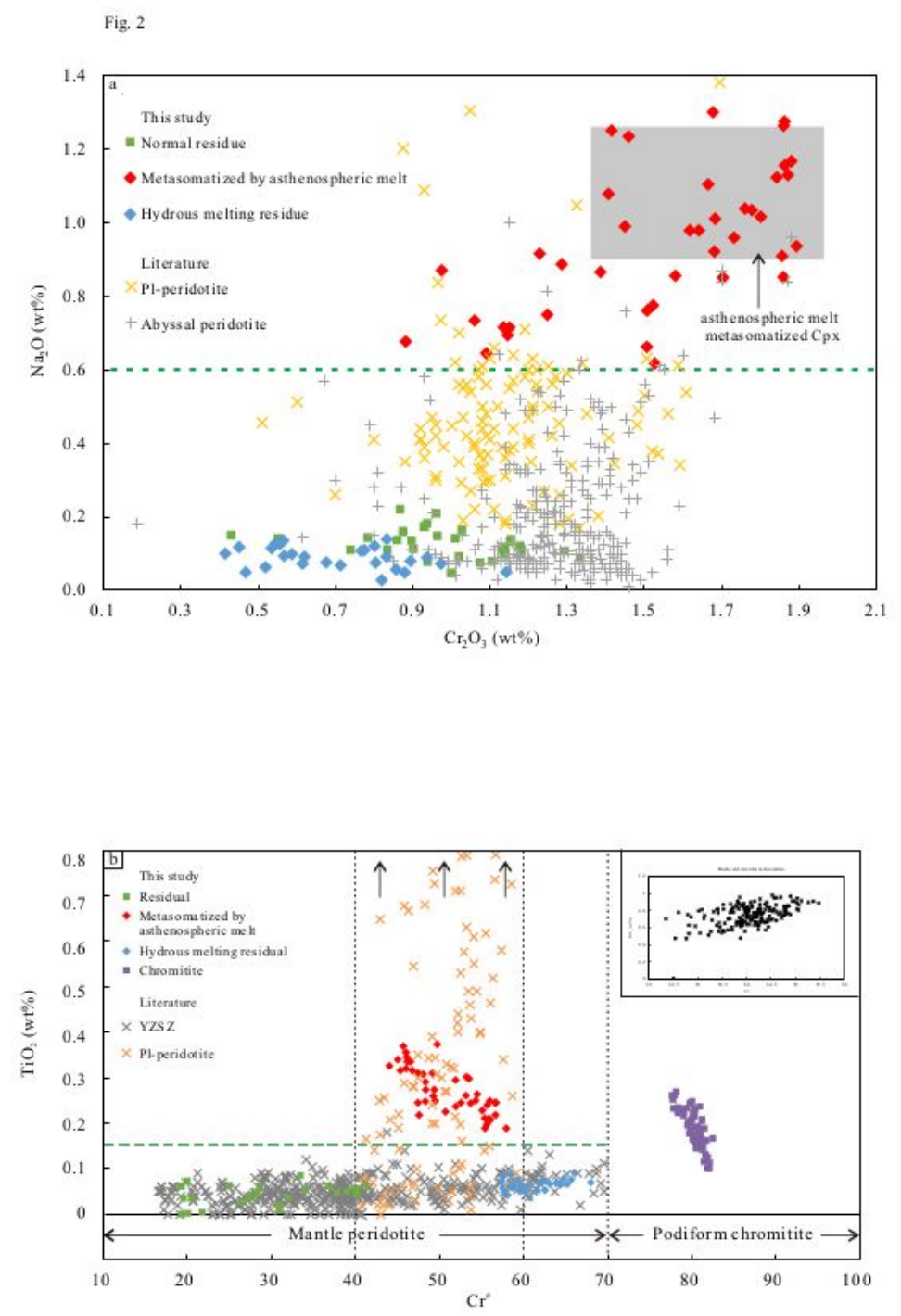

\section{Figure 2}

Major-element compositions of clinopyroxene and chromite. a) $\mathrm{Na} 2 \mathrm{O}$ and $\mathrm{Cr} 2 \mathrm{O} 3$ contents in clinopyroxene. The gray area represents clinopyroxenes from the SWIR metasomatized by asthenospheric melt45. Typical abyssal peridotites are selected only for chromite $\mathrm{Cr} \#$ values of 20 to 40 from the compilation of Warren49. Typical abyssal PI-peridotites are from Brunelli et al.48, Warren et al.50 and Malick et al.54 b) $\mathrm{Cr} \#$ and TiO2 variations of chromite. The dotted green line represents the 
boundary between residual and impregnated peridotites proposed by Dick et al51. Typical abyssal PIperidotites are selected only for chromite $\mathrm{Cr} \#$ values of 40 to 60 from the compilation of Warren49. The Bushveld stratiform chromitite62 and the compilation of accessory chromite from peridotites from the YZSZ are plotted for comparison (see Supplementary Data 4).

Fig. 3
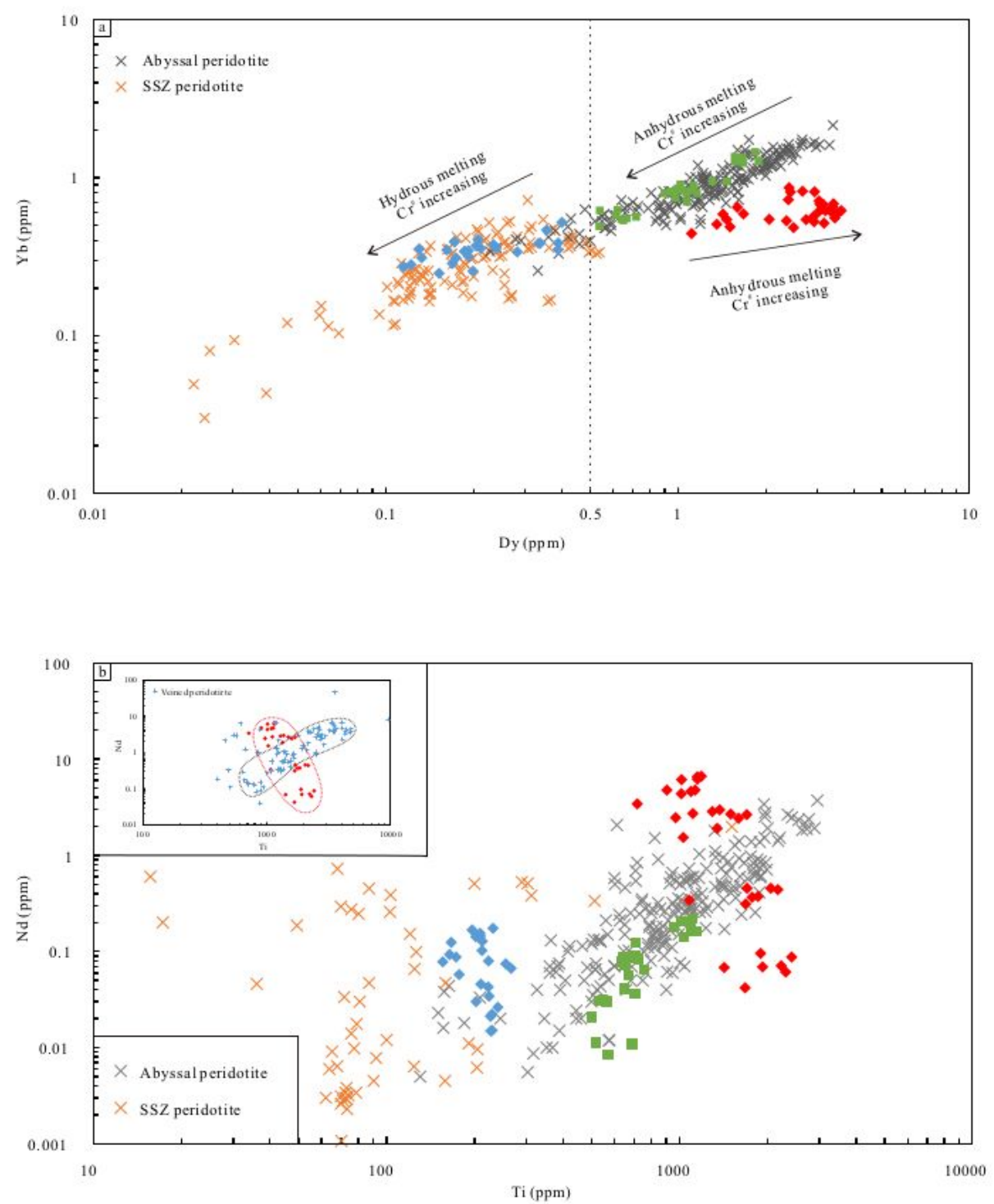

Figure 3 
Trace-element compositions of clinopyroxene. a) Dy-Yb of clinopyroxene in a log-log diagram. Both abyssal49 and SSZ40-43 clinopyroxenes follow the melting trend defined by decreasing $\mathrm{Dy}-\mathrm{Yb}$ with increasing chromite $\mathrm{Cr}$. SSZ clinopyroxenes are selected only for co-existing chromite $\mathrm{Cr} \#$ values of $>5040-43$. Metasomatized clinopyroxenes from this study show an inverse trend to that of melting, characterized by increasing Dy-Yb with increasing chromite $\mathrm{Cr} \#$. b) $\mathrm{Ti}-\mathrm{Nd}$ of clinopyroxene in a log-log diagram. Metasomatized clinopyroxenes define a specific negative trend that differs from that of abyssal residual and veined peridotites (including PI-peridotites) 49 and SSZ peridotites40-43. Same legend as Fig. 2a. 

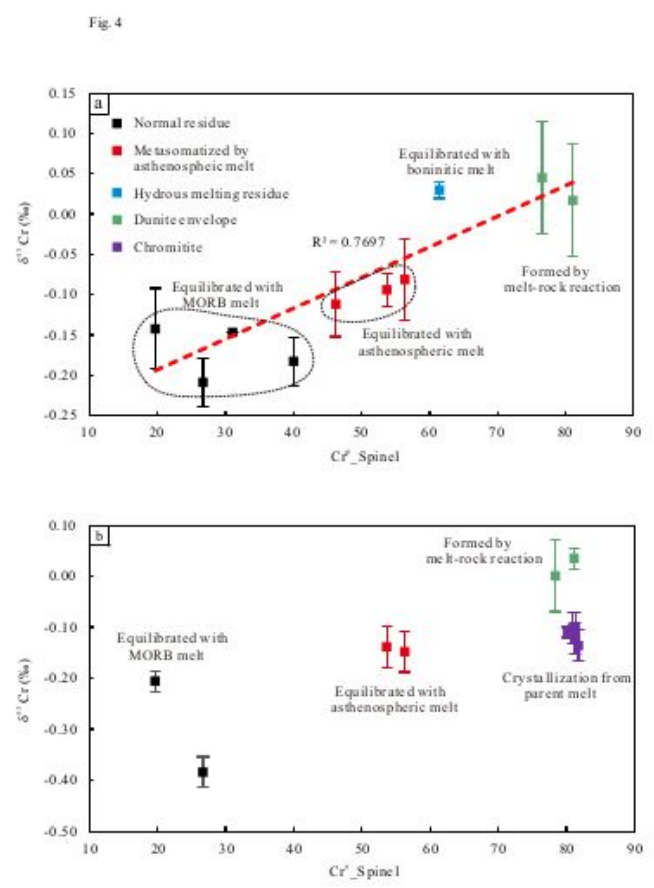

\section{Figure 4}

$\mathrm{Cr}$ isotope compositions of whole-rock and chromite separates. a) Cr isotope compositions of whole rock. b) Cr isotope compositions of chromite separates. 
Fig. 5
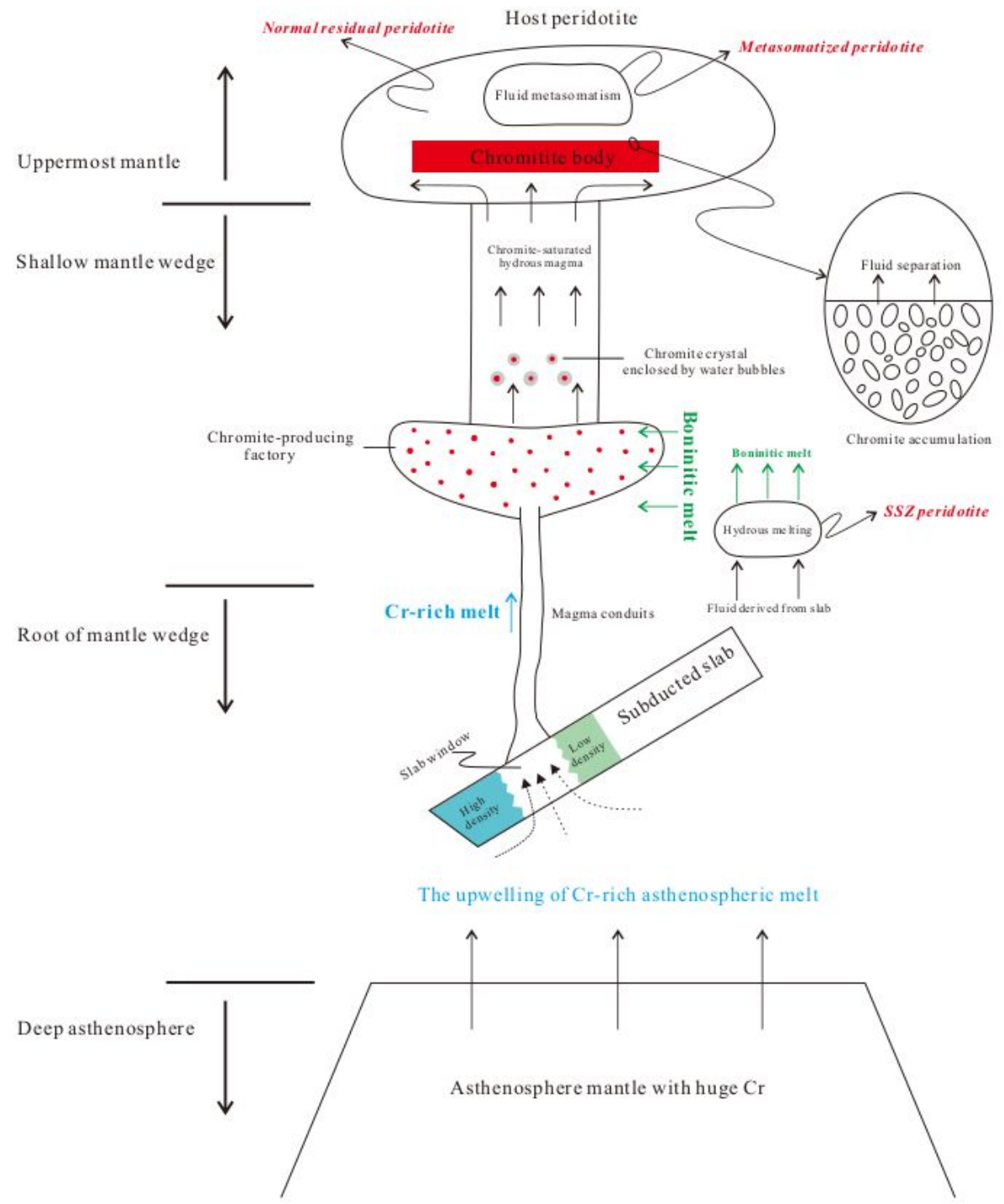

\section{Figure 5}

Proposed model for the formation of podiform chromitite.

\section{Supplementary Files}

This is a list of supplementary files associated with this preprint. Click to download. 
- SupplementaryTableData4TheEPMAdataofchromitefromYarlungZangboophiolite.xlsx

- SupplementaryTableData1Mineralmajorelelmentcompositions.xlsx

- SupplementaryFig.1TeconicsettingofYSZS.pdf

- SupplementaryFig.30remagmatictextures.pdf

- SupplementaryFig.2Petrographicobservations.pdf

- SupplementaryTableData3Crisotopecompositions.xlsx

- Supplementaryinformation.docx

- SupplementaryTableData2CpxandAmptraceelementcompositions.xlsx

- Supplementaryinformation.docx

- SupplementaryFig.4Modellingresultsforboninite.pdf 